II Copier Bhart

RFP-2162
RFP-2162

February 8, 1974

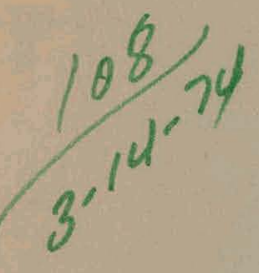

\title{
CORROSION STUDIES IN
}

\section{PLUTONIUM-NITRIC-HYDROFLUORIC SOLUTIONS}

Kazuji Terada

James M. Macki

Marston R. Dringman

David L. Cash

\section{Dow}

(a)

DOW CHEMICAL U.S.A.

ROCKY FLATS DIVISION

P. O. BOX 888

GOLDEN, COLORADO 80401

U.S. ATOMIC ENERGY COMMISSION CONTRACT AT(29-1)-1106 


\section{DISCLAIMER}

This report was prepared as an account of work sponsored by an agency of the United States Government. Neither the United States Government nor any agency Thereof, nor any of their employees, makes any warranty, express or implied, or assumes any legal liability or responsibility for the accuracy, completeness, or usefulness of any information, apparatus, product, or process disclosed, or represents that its use would not infringe privately owned rights. Reference herein to any specific commercial product, process, or service by trade name, trademark, manufacturer, or otherwise does not necessarily constitute or imply its endorsement, recommendation, or favoring by the United States Government or any agency thereof. The views and opinions of authors expressed herein do not necessarily state or reflect those of the United States Government or any agency thereof. 


\section{DISCLAIMER}

Portions of this document may be illegible in electronic image products. Images are produced from the best available original document. 


\section{LEGAL NOTICE}

This report was prepared as an account of work sponsored by the United States Government. Neither the United States nor the United States Atomic Energy Commission, nor any of their employees, nor any of their contractors, subcontractors, or their employees, makes any warranty, expressed or implied, or assumes any legal liability or responsibility for the accuracy, completeness or usefulness of any information, apparatus, product or process disclosed, or represents that its use would not infringe privately owned rights.

Printed in the United States of America

Available from the

National Technical Information Service

U. \&. Department of Commerce

Springfield, Virginia 22151

Price: Printed Copy $\$ 4.00$ Microfiche $\$ 1.45$ 
Printed

February 8, 1974
RFP-2162

UC-10 CHEMICAL SEPARATIONS PROCESSES FOR PLUTONIUM AND URANIUM TID-4500-R60

CORROSION STUDIES IN

\title{
PLUTONIUM-NITRIC-HYDROFLUORIC SOLUTIONS
}

\author{
Kazuii Terada \\ James M. Macki \\ Marston R. Dringman \\ David L. Cash
}

Research and Ecology

PRODUCT AND HEALTH PHYSICS RESEARCH
This report was prepared as an account of work sponsored by the Inited States Fonvernment. Neither the United States nor the United States Atomic Energy Cominission, nor any of their employees, nor any of their contractors, subcontractors, or their employees, makes any warranty, express or implied, or assumes any makes any warranty, express or implied, or assumes any legal liability or responsibility for the accuracy, com- pleteness or usefulness of any information, apparatus,
product or process disclosed, or represents that its use would not infringe privately owned rights.

\section{SUBJECT DESCRIPTORS}

Corrosion

Plutonium

Nitric Acid

Hydrofluoric Acid

Processs Solution

Prepared under Contract AT(29.1).1106

for the

Albuquerque Operations Office

U. S. Atomic Energy Commission 
RFP-2162

\section{CONTENTS}

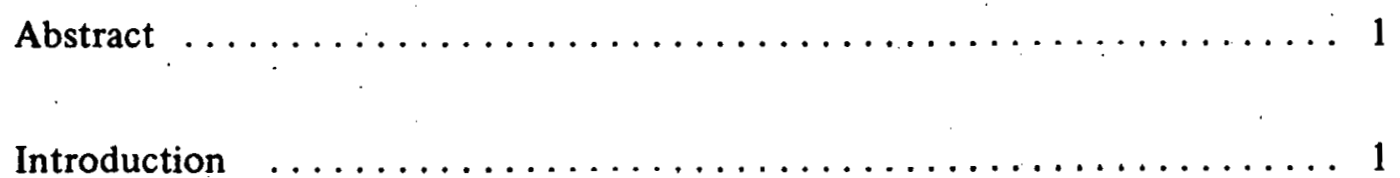

Summary and Conclusions $\ldots \ldots \ldots \ldots \ldots \ldots \ldots \ldots \ldots \ldots$

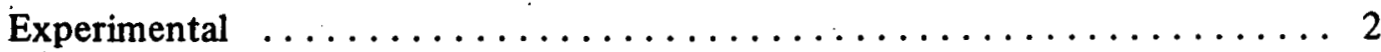

Results and Discussion $\ldots \ldots \ldots \ldots \ldots \ldots \ldots \ldots \ldots \ldots \ldots \ldots$

References $\ldots \ldots \ldots \ldots \ldots \ldots \ldots \ldots \ldots \ldots \ldots \ldots \ldots \ldots \ldots$ 


\title{
CORROSION STUDIES IN PLUTONIUM-NITRIC-HYDROFLUORIC SOLUTIONS
}

\author{
Kazuji Terada, James M. Macki, Marston R. Dringman, and David L. Cash
}

\begin{abstract}
Several alloys were evaluated as possible construction material in chemical processing equipment for plutonium at Rocky Flats. Corrosion studies were made of these alloys in solutions obtained from a production storage tank. The principal components of these solutions were nitric acid, hydrofluoric acid, and plutonium. Results showed relative concentrations of these components can significantly affect corrosion rates. Of the alloys tested, Inconel 690 exhibited the lowest corrosion rates in the process solutions. E-Brite 26-1 also showed corrosion resistance greater than 304L stainless steel.
\end{abstract}

\section{INTRODUCTION}

In the chemical processing of plutonium for weapons and fuels applications, plutonium as metal, oxide, or fluoride is dissolved in boiling $\mathrm{HNO}_{3}-\mathrm{HF}$ solutions. This acid combination is very corrosive to metals and presents a containment problem regarding the highly radioactive process solution. A number of reports on corrosion rates of different alloys in $\mathrm{HNO}_{3}-\mathrm{HF}$ solutions have been published.$^{1-5}$

Alloys having the greatest resistance to corrosion are high nickel-chromium alloys such as HAPO 20 ( 56 wt \% nickel - 36 wt \% chromium) and Corronel 230 (50 wt \% nickel - 25 wt \% chromium). Corrosion rates of unwelded HAPO 20 and Corronel 230 in boiling $13 \mathrm{M} \mathrm{HNO}-\mathrm{HF}$ solution after 24 hours were 32 and $17 \mathrm{mil} / \mathrm{month}$, respectively. ${ }^{1}$ These corrosion rates are normally considered too high. In addition, HAPO 20 and Corronel 230 are experimental alloys and are not commercially avallable.

Plastics can sometimes be used in place of metals; but there are many situations where plastics are not suitable. Some of the reasons are flammability, low heat-exchange properties; and low temperature tolerance compared to metal.

At Rocky Flats, 304L stainless steel has been used in the processing of plutonium in $\mathrm{HNO}_{3}$-HF solutions. The steel has corrosion rates significantly lower than $17 \mathrm{mils} / \mathrm{month}$. This lower rate is due to (1) generally lower concentration of fluoride in the process stream, (2) lower overall temperature of the solute, and (3) the presence of plutonium in the solution. Corrosion rates are known to be highly dependent on the HF concentration. 2,5 The fluoride-ion concentration in Rocky Flats solutions can vary considerably, but it is generally about 0.05 molar. Solutions are kept at boiling temperature during actual dissolution, but during most other processing steps involving the solution, the temperature varies down to room temperature. Plutonium, like the aluminum ion, complexes quite strongly with fluoride ions and decreases the effective concentration of hydrofluoric acid. This in turn lowers the solution's corrosive effect on 304L stainless steel.

Previous to this work, no corrosion studies have been made under Rocky Flats process conditions to determine actual corrosion rates. In this work, tests were made to obtain this information. In addition, several new and old alloys were tested to seek a suitable replacement for 304L stainless steel to contain process solutions.

\section{SUMMARY AND CONCLUSIONS}

Test results show the relative concentrations of $\mathrm{HNO}_{3}$-HF-Pu in process solutions greatly affect 
the corrosion rates of process equipment. By carefully controlling these concentrations, corrosion rates can be lowered, thereby increasing equipment life by years. Where it is necessary to use solutions that are highly corrosive to $304 \mathrm{~L}$ stainless steel, use of more expensive Inconel 690 would ultimately result in greater economy. E-Brite 26-1, having a cost between that for $304 \mathrm{~L}$ stainless steel and Inconel 690, could also be useful in $\mathrm{HNO}_{3}-\mathrm{HF}$ environments. However, it should be remembered that E-Brite 26-1 requires heat treatment after welding and this is not always possible in the process lines.

\section{EXPERIMENTAL}

Corrosion tests were conducted in Teflon ${ }^{*}$ pots 6 in. in diameter and 12 in. high. Each pot was covered with a tight fitting Teflon lid that had openings for an immersion heater, reflux condenser, and a thermometer. The immersion heater was made with an external quartz jacket, and the quartz was protected from the HF by Teflon tape. Teflon was also used for constructing "wetted" parts of the water-cooled reflux condenser whereas glass or plastic was used for the outer cooling jacket. Intermittent temperature measurements were made by passing a mercury thermometer through a hole in the lid of the reaction pot and into the solution. For most of the test duration, the hole was stoppered with a Teflon plug to prevent vapor leakage.

The presence of plutonium in the test solution necessitated enclosing the equipment in a glovebox; also separating the pots to prevent any possibility of creating a critical mass. The pots were kept apart by placing each in the middle of a $24-$ in.diameter spacer ring.

Process solutions were used for the test medil. These were obtained from the holding tanks into which solutions from the cascade dissolvers were stored for processing. They were regarded as typical of the process solutions and their analyses are listed in Tables 1, 2, and 3.

\footnotetext{
* Trademark of E. I. duPont deNemours and Company.
}

Table 1. First Series of Planned-Interval Tests.

\begin{tabular}{|c|c|c|c|}
\hline \multirow[b]{2}{*}{ Specimen } & \multicolumn{2}{|c|}{ Corrosion Rates (mpy)* } & \multirow{2}{*}{$\begin{array}{l}\text { Concentration } \\
\text { of Solution }\end{array}$} \\
\hline & in Solution & in Vapor & \\
\hline \multicolumn{4}{|c|}{ After First 24 Hours } \\
\hline 304L & $\begin{array}{l}167 \\
178\end{array}$ & $\begin{array}{l}161 \\
165\end{array}$ & $\begin{array}{l}39.3 \mathrm{~g} / \text { liter } \mathrm{Pu} \\
12.0 \mathrm{molar} \mathrm{H}^{+}\end{array}$ \\
\hline 309 & $\begin{array}{l}136 \\
126\end{array}$ & $\begin{array}{l}109 \\
112\end{array}$ & $1.02 \mathrm{~g} /$ liter $\mathrm{F}^{-}$ \\
\hline Carpenter & 191 & 240 & \\
\hline $20 \mathrm{Cb}-3$ & 194 & 112 & $\begin{array}{l}38.7 \mathrm{~g} / \text { liter } \mathrm{Pu} \\
12.2 \mathrm{molar} \mathrm{H}^{+}\end{array}$ \\
\hline Inconel 690 & $\begin{array}{l}38 \\
39\end{array}$ & $\begin{array}{l}38 \\
38\end{array}$ & $1.1 \mathrm{~g} /$ liter $\mathrm{F}^{-}$ \\
\hline F-Brite 26-1 & $\begin{array}{l}70 \\
70\end{array}$ & $\begin{array}{l}65 \\
61\end{array}$ & $\begin{array}{l}38.9 \mathrm{~g} / \text { liter } \mathrm{Pu} \\
12.2 \text { molar }^{+}\end{array}$ \\
\hline $\begin{array}{l}\text { E-Brite } 26-1 \\
\text { Welded and } \\
\text { Heat Treated }\end{array}$ & $\begin{array}{l}71 \\
70\end{array}$ & 71 & $1.08 \mathrm{~g} /$ liter $\mathrm{F}^{-}$ \\
\hline
\end{tabular}

After Additional 46 Hours

\begin{tabular}{|c|c|c|c|}
\hline $304 \mathrm{~L} * *$ & $\begin{array}{l}212 \\
174\end{array}$ & $\begin{array}{l}191 \\
200\end{array}$ & $\begin{array}{l}39.3 \mathrm{~g} / \text { liter } \mathrm{Pu} \\
12.6 \mathrm{molar} \mathrm{H}^{+}\end{array}$ \\
\hline $309 * *$ & $\begin{array}{l}139 \\
135\end{array}$ & $\begin{array}{l}137 \\
136\end{array}$ & $1.10 \mathrm{~g} /$ liter $\mathrm{F}^{-}$ \\
\hline Carpenter & 321 & 269 & \\
\hline $20 \mathrm{Cb}-3$ & 378 & 265 & $\begin{array}{l}40.5 \mathrm{~g} / \text { liter } \mathrm{Pu} \\
12.7{\mathrm{molar} \mathrm{H}^{+}}^{+}\end{array}$ \\
\hline Inconel 690 & $\begin{array}{l}45 \\
44\end{array}$ & $\begin{array}{l}40 \\
39\end{array}$ & $1.14 \mathrm{~g} /$ liter $F^{-}$ \\
\hline E-Brite 26-1 & $\begin{array}{l}151 \\
151\end{array}$ & $\begin{array}{l}106 \\
101\end{array}$ & $\begin{array}{l}40.8 \mathrm{~g} / \text { liter } \mathrm{Pu} \\
12.8 \mathrm{molar}^{+}\end{array}$ \\
\hline $\begin{array}{l}\text { E-Brite } 26-1 \\
\text { Welded and } \\
\text { Heat Treated }\end{array}$ & $\begin{array}{l}62 \\
64\end{array}$ & 61 & $1.00 \mathrm{~g} /$ liter $\mathrm{F}^{-}$ \\
\hline
\end{tabular}

After Final 24 Hours

\begin{tabular}{|c|c|c|c|}
\hline $\begin{array}{l}\text { Carpentor } \\
20 \mathrm{Cb}-3\end{array}$ & $\begin{array}{l}487 \\
363\end{array}$ & $\begin{array}{l}272 \\
262\end{array}$ & $\begin{array}{l}40.8 \text { g/liter } \mathrm{Pu} \\
13.6 \text { molar }^{*}\end{array}$ \\
\hline Ineonol 690 & $\begin{array}{l}38 \\
39\end{array}$ & $\begin{array}{l}38 \\
38\end{array}$ & $1.14 \mathrm{~g} / 1 \mathrm{ltor} \mathrm{F}^{\mathrm{B}}$ \\
\hline E-Brite 26-1 & $\begin{array}{l}199 \\
197\end{array}$ & $\begin{array}{l}133 \\
127\end{array}$ & $\begin{array}{l}41.6 \mathrm{~g} / \text { Ller } \mathrm{Bu} \\
13.08 \text { molar } \mathrm{H}^{*}\end{array}$ \\
\hline $\begin{array}{l}\text { E-Brite 26-1 } \\
\text { Welded and } \\
\text { Heat Treated }\end{array}$ & 49 & 48 & $1.12 \mathrm{~g} /$ Lter $\mathrm{P}^{=}$ \\
\hline
\end{tabular}


Table 2. Second Series of Planned-Interval Tests.

Specimen $\begin{array}{ll}\begin{array}{l}\text { Corrosion Rates (mpy)* } \\ \text { in Solution in Vapor }\end{array} & \begin{array}{l}\text { Concentration } \\ \text { of Solution }\end{array}\end{array}$

After First 24 Hours

$304 \mathrm{~L}$

21
19

309

E-Brite 26-1

E-Brite 26-1

Inconel 690

Inconel 690

690

After Additional 42 Hours

$304 \mathrm{~L}$

309

E-Brite 26-1

11

E-Brite 26-1

12

13

$\left.\begin{array}{l}22 \\ 22 \\ 17 \\ 18\end{array}\right\}$

$47.9 \mathrm{~g} /$ liter $\mathrm{Pu}$ 9.0 molar $^{+}$ $0.74 \mathrm{~g} /$ liter $\mathrm{F}^{-}$

$9 \mathrm{~g}^{2}$

47.5 g/liter $\mathrm{Pu}$ $10.9{\text { molar } \mathrm{H}^{+}}^{+}$ $0.66 \mathrm{~g} /$ liter $\mathrm{F}^{-}$

$46.8 \mathrm{~g} /$ liter $\mathrm{Pu}$ $10.2 \mathrm{molar}^{\mathrm{H}^{+}}$

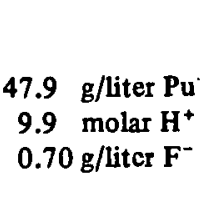

Inconel 690

22

Inconel 690

28

29

After Final 24 Hours

$304 L$

309

$\left.\begin{array}{lll}\text { E-Arite 26-1 } & 19 & 28 \\ & 18 & 31 \\ \text { E-Bite 26.1 } & 20 & 28 \\ & 21 & 30\end{array}\right\}$

- mill per year 9.4 molar $^{+}$ $0.80 \mathrm{~g} /$ liter $\mathrm{F}^{-}$

48.0 g/liter $\mathrm{Pu}$ 9.2 molar $\mathrm{H}^{+}$ 0.82 molar $\mathrm{F}^{-}$

$47.4 \mathrm{~g} / \mathrm{Hter} \mathrm{Pu}$

9.4 molar $^{+}$

$0.66 \mathrm{~g} /$ Hter $\mathrm{F}^{\mathrm{x}}$

$48.8 \mathrm{~g} / \mathrm{Lter} \mathrm{Pu}$ 9.5 molar $H^{+}$ $0.79 \mathrm{~g} /$ Lte: $\mathrm{F}^{-}$

$57.4 \mathrm{~g} / \mathrm{Hter} \mathrm{Pu}$ 10.8 molar $^{+}$ $0.88 \mathrm{~g} / \mathrm{Wter} \mathrm{F}^{\mathrm{C}}$ $0.70 \mathrm{~g} /$ litcr $F^{-}$

Table 3. Third Series of Planned-Interval Tests.

Specimen $\begin{array}{ll}\begin{array}{c}\text { Corrosion Rates (mpy)* } \\ \text { in Solution in Vapor }\end{array} & \begin{array}{l}\text { Concentration } \\ \text { of Solution }\end{array}\end{array}$

After First 24 Hours

\begin{tabular}{|c|c|c|c|}
\hline 304L & $\begin{array}{l}133 \\
165\end{array}$ & $\begin{array}{l}161 \\
172\end{array}$ & $\begin{array}{ll}14.9 & \mathrm{~g} / \text { liter } \mathrm{Pu} \\
13.4 & \text { molar } \mathrm{H}^{+}\end{array}$ \\
\hline 309 & $\begin{array}{l}168 \\
121\end{array}$ & $\begin{array}{l}174 \\
117\end{array}$ & $0.41 \mathrm{~g} /$ liter $\mathrm{F}^{-}$ \\
\hline E-Brite 26-1 & 68 & 66 & \\
\hline $\begin{array}{l}\text { Welded and } \\
\text { Heat Treated }\end{array}$ & 75 & 74 & $\begin{array}{l}15.0 \text { g/liter } \mathrm{Pu} \\
12.9 \text { molar } \mathrm{H}^{+}\end{array}$ \\
\hline $\begin{array}{l}\text { E-Brite } 26-1 \\
\text { Heat Treated }\end{array}$ & $\begin{array}{l}75 \\
76\end{array}$ & $\begin{array}{l}68 \\
70\end{array}$ & $0.48 \mathrm{~g} /$ liter \\
\hline Inconel 690 & 65 & 53 & \\
\hline Welded & 69 & 66 & $\begin{array}{l}15.16 \mathrm{~g} / \text { liter } \mathrm{Pu} \\
13.8 \mathrm{molar} \mathrm{H}^{+}\end{array}$ \\
\hline $\begin{array}{l}\text { Inconel } 690 \\
\text { Welded }\end{array}$ & $\begin{array}{l}55 \\
46\end{array}$ & $\begin{array}{l}50 \\
42\end{array}$ & $0.49 \mathrm{~g} /$ liter $\mathrm{F}^{-}$ \\
\hline
\end{tabular}

$304 \mathrm{~L}$

After Additional 46 Hours

$\left.\begin{array}{ll}168 & 187 \\ 270 & 203 \\ 171 & 147 \\ 149 & 148\end{array}\right\} \begin{array}{rr}14.5 \mathrm{~g} / \text { liter } \mathrm{Pu} \\ 12.4 \mathrm{molar} \mathrm{H}^{+} \\ 0.41 \mathrm{~g} / \text { liter } \mathrm{F}^{-}\end{array}$

E-Brite 26-1

Welded and

Heat Treated

$49.6 \mathrm{~g} /$ liter $\mathrm{Pu}$

E-Brite 26-1

Heat Treated

50

51

52

16.8 g/liter Pu

13.0 molar $\mathrm{H}^{+}$

0.49 g/liter $\mathrm{F}^{-}$

Inconel 690

Welded

Inconel 690

Welded

$304 \mathrm{~L}$

309

49

52

53

53

$\left.\begin{array}{ll}50 & 35 \\ 50 & 40 \\ 44 & 37 \\ 44 & 31\end{array}\right\}$

$16.4 \mathrm{~g} /$ liter $\mathrm{Pu}$

12.8 molar $^{+}$

$0.53 \mathrm{~g} /$ liter $\mathrm{F}^{-}$

After Final 24 Hours

167

162

206

223

153

224

167

170

\begin{tabular}{|c|c|c|c|}
\hline $\begin{array}{l}\text { E-Brite 26-1 } \\
\text { Welded and } \\
\text { Heat Treated }\end{array}$ & $\begin{array}{l}38 \\
35\end{array}$ & $\begin{array}{l}29 \\
40\end{array}$ & $\begin{array}{c}40.6 \mathrm{WH} / \mathrm{g} / \mathrm{liter} \mathrm{Pu} \\
9.6 \mathrm{molar} \mathrm{H}^{+}\end{array}$ \\
\hline $\begin{array}{l}\text { Eerrite 26-1 } \\
\text { Heat Treated }\end{array}$ & $\begin{array}{l}35 \\
36\end{array}$ & $\begin{array}{l}40 \\
40\end{array}$ & $0.38 \mathrm{~g} /$ liter $F$ \\
\hline Inconel 690 & 40 & 29 & \\
\hline Welded & 40 & 30 & $\begin{array}{l}15.1 \text { g/liter } \mathrm{Pu} \\
10.8 \text { molar } \mathrm{H}^{+}\end{array}$ \\
\hline $\begin{array}{l}\text { Inconel } 690 \\
\text { Welded }\end{array}$ & $\begin{array}{l}39 \\
37\end{array}$ & $\begin{array}{l}30 \\
27\end{array}$ & $0.5 \mathrm{~g} /$ Liter $\mathrm{F}^{-}$ \\
\hline
\end{tabular}

- mils per year

* Probable analytical error
$14.46 \mathrm{~g} /$ liter $\mathrm{Pu}$ 11.2 molar $\mathrm{H}^{+}$ $0.48 \mathrm{~g} /$ liter $\mathrm{F}^{-}$

8 molar $\mathrm{H}^{+}$ $0.5 \mathrm{~g} /$ liter $\mathrm{F}^{-}$ 
Samples of E-Brite $26-1 \AA^{*}$ and Inconel $690 \otimes^{* *}$ alloys were obtained from the manufacturers. The remaining steel samples were commercial, 2-in. disks designed for corrosion tests. These disks were quartered to reduce each specimen's surface area. To obtain good corrosion data it is recommended that $250 \mathrm{ml}$ of corrosion solution be used for every square inch of surface area ${ }^{6}$. Because of nuclear criticality considerations, the volume of solution had to be greatly reduced and a volumeto-area ratio of $100 \mathrm{ml}$ of solution to $1 \mathrm{sq}$. in. of surface area was used in the tests.

With the exception of E-Brite 26-1 and Inconel 690 , the alloy samples as received were simply cleaned in $65 \% \mathrm{HNO}_{3}$ before testing. Some of the E-Brite 26-1 and Inconel 690 samples were subjected to welding and heat treatment prior to testing. The types of welds were open air TIG weld, "inert" chamber TIG weld, and electron beam weld. The heat treatment of E-Brite 26-1 involved annealing for 1 hour at $1400^{\circ} \mathrm{F}$ and then water quenching. Inconel 690 was annealed at $2150^{\circ} \mathrm{F}$ for 1 hour and water quenched. Duplicate samples were immersed in the test solutions and suspended in the hot vapors.

Most of the corrosion studies utilized a modified "Planned-Interval Test" method" in which corrosion rates were determined after three time intervals with the first and third time interval being 24 hours. It was hoped the maximum amount of information could be obtained by this procedure rather than extensive experimentation for prolonged periods.

The "Planned-Interval Test" was modified because nuclear criticality considerations precluded using large volumes and necessitated smaller pots separated by at least 2 feet. The availability of glovebox space for only a limited time also contributed to the decision to modify the "Planned-Interval Test."

\section{RESULTS AND DISCUSSION}

Results of the three series of tests are summarized in Tables 1, 2, and 3. Just a cursory glance through

\footnotetext{
* Trademark of the Alrco Vacuum Metals Company.

* Trademark of the Internatlonal Nickel Company.
}

the tables provides an indication that the process solutions can be highly corrosive. Table 1 shows the austenitic stainless steels (304L, 309, and Carpenter $20 \mathrm{Cb}-3$ ) have significantly lower corrosion resistance than the ferritic stainless steel (E-Brite 26-1) and nickel-chromium-iron alloy (Inconel 690). Only Inconel 690 had corrosion rates under 50 mils per year.

In contrast, the results of the second series of tests, listed in Table 2, show all the specimens had corrosion rates of less than 50 mils per year. Test solutions in the first series started with about $40 \mathrm{gm} /$ liter $\mathrm{Pu}, 12$ molar in $\mathrm{HNO}_{3}$ and $1.1 \mathrm{gm} /$ liter $\mathrm{F}^{-}$. The concentration of the solution for the second series was about $47 \mathrm{gm} /$ liter $\mathrm{Pu}, 10$ molar in $\mathrm{HNO}_{3}$, and $0.7 \mathrm{gm} / \mathrm{liter} \mathrm{F}^{-}$. The concentrations do not differ greatly, but the corrosion rates show significant differences.

Results of the third series of tests are listed in Table 3. Corrosion rates are generally quite high although the fluoride ion concentrations are relatively low. The high rates are due probably to the comparatively low plutonium and high acid concentrations.

Where corrosion rates are low, the difference in corrosion resistance of the alloy decreases.

Table 2 shows the E-Brite 26-1 has lower corrosion rates than Inconel 690 , and the corrosion resistance of $304 \mathrm{~L}$ stainless steel is comparable to that of Inconel 690.

The modified "Planned-Interval Tests" were conducted to determine whether the metals become more susceptible to corrosion with time. For example, all three tables show that some motals exhibited higher corrosion rates during the final 24 hours than the initial 24 -hour test period. This was due either to the increased corrosion susceptibility of the metal or the increased corrosivity of the liquids. The corrosivity of the liquid arises from the $\mathrm{HNO}_{3}-\mathrm{HF}$ combination in solution, and during the tests, some of the acld and water is lost. From the binary azeotropic data on the $\mathrm{H}_{2} \mathrm{O}-\mathrm{HNO}_{3}$ and $\mathrm{H}_{2} \mathrm{O}-\mathrm{HF}$ systems, proportionately more water than acid would be expected to vaporize. The acid concentration of the solution should therefore be increased. 
Table 4: Concentration of the Three Test Solutions.

$$
\begin{gathered}
\text { Analytical Results } \\
\text { (moles/liter) }
\end{gathered}
$$

\begin{tabular}{|c|c|}
\hline Solution & $\mathbf{P u}$ \\
\hline I & 0.17 \\
\hline II & 0.20 \\
\hline III & 0.062 \\
\hline
\end{tabular}

Calculated Results (moles/liter)

$\begin{array}{cccc}\frac{\mathrm{PuF}^{+3}:}{0_{0.057}} & \frac{\mathrm{Pu}^{+4}}{0.11} & \frac{\mathrm{HF}}{1.4 \times 10^{-3}} & \frac{\mathrm{F}^{-}}{8.5 \times 10^{-8}} \\ 0.036 & 0.16 & 5.3 \times 10^{-4} & 3.9 \times 10^{-8} \\ 0.022 & 0.040 & 1.7 \times 10^{-3} & 9.0 \times 10^{-8}\end{array}$

At the same time, the concentration of plutonium is increased to a greater degree than the acid, because of its nonvolatility.

The overall effect is that the corrosivity of the solution is decreased. This statement is based on corrosion tests made in a solution of initially $12 \mathrm{M} \mathrm{HNO}_{3}, 0.5 \mathrm{M} \mathrm{HF}$, and $0.5 \mathrm{M} \mathrm{AL}\left(\mathrm{NO}_{3}\right)_{3}$. Aluminum nitrate was used as a fluoride complexing agent in place of plutonium. Half of the solution was boiled off and the tests were repeated in the remaining liquid. Results of 24-hour corrosion tests showed the original and concentrated solutions were 117 and $65 \mathrm{mpy}$, respectively. Therefore, corrosivity of the test solution at boiling temperatures decreased with time. Any increase in corrosion rate must be attributed to increased corrosion susceptibility of the alloys and not to the solution.

Table 4 shows the analyzed concentrations of $\mathrm{H}^{+}$, $\mathrm{F}^{-}$, and $\mathrm{Pu}^{+4}$ of the three test solutions and the calculated concentrations of other chemical species in the solutions.

These concentrations are based on representative analytical results of the three solutions. A computer was used in making the calculations, and it was assumed that under the test conditions only one plutonium complex, $\mathrm{PuF}^{+3}$, was formed. According to McLane ${ }^{8}$ the difluoride complex is not formed until the HF/Pu ratio reaches about 6 and this ratio was not approached in any of the test solutions. The stability constant used for $\mathrm{PuF}^{+3}$ was $5.9 \times 10^{6}$ and for the dissociation constant of $\mathrm{HF}, 7.2 \times 10^{-4}$ was used. The stability constant for $\mathrm{PuF}_{2}^{+2}$ is not known.

The calculated values in Table 4 are in agreement with the experimental results. Table 4 shows that $\mathrm{HF}$, one of the key corrosive reagents, is lowest in solution II and results from corrosion tests showed solution II was less corrosive than the other two solutions although it contained about $50 \%$ more fluoride than solution III. This difference was due to the complexing of the $\mathrm{F}^{-}$by $\mathrm{Pu}^{+4}$ which had a higher $\mathrm{Pu}$ concentration in solution II than solution III and offset the higher total fluoride concentration in the former solution. The effective $\mathrm{HF}$ and $\mathrm{HNO}_{3}$ concentrations in solutions I and III are comparable according to the calculations, and their corrosion rates as shown in Tables 1 and 2 are also comparable.

Solution II was the least corrosive of the three test solutions by a significant factor. Its $\mathrm{HNO}_{3}$ concentration, while lower than the other two, does not appear to be significantly different at first glance. This indicates that within the range of concentrations of the process solutions, there is considerable variation in corrosivity. By carefully controlling the relative concentrations of $\mathrm{Pu}-\mathrm{HNO}_{3}$ $\mathrm{HF}$ in the solutions, corrosion rates can be reduced to an acceptable level-even for 304L stainless steel. Although Table 2 shows the corrosion rates of $304 \mathrm{~L}$ stainless steel to be of marginal utility, it must be recognized that the tests were conducted at boiling temperatures while the actual processes, for the most part, are performed at lower temperatures. 


\section{REFERENCES}

1. P. D. Miller, E. F. Stephans, W. E. Berry, and W. K. Boyd, "Corrosion of Construction Materials in Boiling 13M Nitric-0.1M Hydrofluoric Acid," Report BMI-X-434, Battelle Memorial Institute, March 30, 1967.

2. W. E. Clark and R. E. Blanco, "Dissolution of LMFBR Fuels: Survey of the Corrosion of Selected Alloys in $\mathrm{HNO}_{3}$-HF Solutions," Oak Ridge National Laboratory Report ORNL-4745, December 1971.

3. T. A. Arehart and T. C. Runion, "Corrosion of Stainless Steel by $\mathrm{HNO}_{3} \mathrm{HF}$ - $\mathrm{Al}\left(\mathrm{NO}_{3}\right)_{3}$ Mixtures During Evaporation of Plutonium Product Streams," O ak Ridge National Laboratory C'entral Files Number CF.52-11-76, November 10, 1952.

4. W. L. Walker, "Inhibition of $\mathrm{HNO}_{3}$-HF Corrosion of Type 304L Stainless Steel with $\mathrm{Al}\left(\mathrm{NO}_{3}\right)_{3} \cdot 9 \mathrm{H}_{2} \mathrm{O}$,"
General Electric Report HW.53636, November 18, 1957.

5. P. M. Kranzlein, "Corrosion of Stainless Steel in $\mathrm{HNO}_{3}$-HF Solutions," Savannah River Laboratory Report DP486, July 1960.

6. "Test Method: Laboratory Corrosion Testing of Metals for the Process Industries," NACE Standard TM-01-69, March 1969.

7. M. G. Fontana and N. D. Greene, Corrosion Engineering, McGraw-Hill Book Company, New York, (1967), p. 125 .

8. The Transuranium Elements IV:14B, edited by Glenn T. Seaborg, J. J. Katz, and W. M. Manning, McGraw-Hill Book Company, New York, (1949), p. 414. 